JOLANTA WASILEWSKA - LUBLIN

\title{
PAMIĄTKA - ŚWIĘTOŚĆ CZY TALIZMAN? DLACZEGO ZBIERAMY OBRAZKI ŚWIĘTE?
}

W większości naszych domów można znaleźć obrazki święte (nazywane także: dewocyjnymi, religijnymi, popularnymi) ${ }^{1}$, powkładane między kartki Biblii, śpiewników, książeczek do nabożeństwa, pochowane w szufladach, gdzieniegdzie jak dawniej włożone za ramy obrazów, jako zakładki w modlitewnikach, a nawet w czytanych książkach; nosimy je w portfelach i torebkach, umieszczamy je w samochodach, towarzyszą nam często w podróży i w pracy. Obrazki święte są także pamiątkami po bliskich nam osobach, przypominają wydarzenia z życia wspólnoty Kościoła jak przyjmowanie sakramentów: Chrztu, Pierwszej Komunii, Bierzmowania itd., wstapienie do grona ministrantów, święcenia kapłańskie, odbyte rekolekcje, misje parafialne, wizyty duszpasterskie, pielgrzymki do świętych miejsc. Spełniają ważną rolę w naszym życiu religijnym, przypominają o codziennej modlitwie i wypełnianiu przykazań Bożych.

Otrzymujemy je w listach wraz z życzeniami i błogosławieństwem. Bywają wkładane zmarłym do trumny, aby towarzyszyły im w drodze do wieczności.

Rozprowadzane są najczęściej przez Kościół, choć dawniej można je było nabywać na odpustach i jarmarkach, bądź za pośrednictwem obwoźnych sprzedawców. Obecnie najpowszechniejszą formą rozdawania obrazków są doroczne wizyty duszpasterskie. Wydawane są w celu popularyzowania miejsc świętych i kultu czczonych w nich świętych wizerunków. Trafiają do odbiorców jako wota po nawiedzaniu tych miejsc. Obrazki święte znalazły się także w sferze zainteresowania kolekcjonerów.

Obrazki dewocyjne funkcjonują zatem jako różne kategorie przedmiotów i pojęć, należą do świata religii, świata sztuki, świata przedmiotów codziennego użytku².

${ }^{1}$ H. Kuś, Obrazek popularny w polskiej kulturze religijnej, Biała Podlaska 1984, s. 3-4

${ }^{2}$ A. Bereza, Sposób funkcjonowania wspótczesnego obrazka dewocyjnego, Konteksty nr 1-2, Warszawa 2002, s. 135 


\section{Krótka historia}

Dokładną datę pojawienia się świętych obrazków trudno ustalić. Pierwsze obrazki święte, wraz z rozwojem drzeworytnictwa, pojawiły się pod koniec XIV wieku na terenie Włoch, Niemiec, Flandrii a następnie Francji. Były wzorowane na miniaturowych ilustracjach ze średniowiecznych modlitewników wytwarzanych w klasztorach i sanktuariach pielgrzymkowych (wizerunki świętych na iluminacjach mogły być też wyrywane z książeczek). Jednak pierwszym udokumentowanym obrazkiem świętym jest obrazek z postacią św. Krzysztofa, datowany na rok $1423^{3}$.

Istnieje także legenda dotycząca pierwszego obrazka w historii. W XVI wieku żył pobożny franciszkanin Bernardyn ze Sieny, który przemierzając kraj wzywał ludzi do nawrócenia. Był wielkim przeciwnikiem bogato zdobionych ubiorów, peruk i ozdób, szczególną nienawiść żywił do gry w karty i kości. W jednym z miast wygłosił tak płomienne kazanie, że słuchacze porwani jego słowami zebrali wszystkie przedmioty zbytku i je spalili. Po tym wydarzeniu do zakonnika zgłosił się miejscowy rzemieślnik, dotąd trudniący się wyrobem kart i kości do gry ze skargą. Stracił on klientów i widmo biedy zajrzało jemu i jego rodzinie w oczy. Bernardyn wziął do ręki kartę (prawdopodobnie tę do gry), narysował na niej koło i wpisał w nie imię Jezusa. Następnie nakazał rzemieślnikowi produkować takie karty. Jak głosi legenda, rzemieślnik ten niesłychanie się wzbogacił .

Przez cały XV wiek na terenach Niemiec powstało najwięcej warsztatów zajmujących się produkcją matryc drzeworytowych do odbijania obrazków. Był to złoty okres produkcji obrazków świętych.

Do czasów reformacji centrum produkcji obrazków świętych były Niemcy i Belgia. Obrazki święte okazały się doskonałym narzędziem w rękach kontrreformatów. Dzięki nim jezuici rozpowszechniali symbole religijne, sceny biblijne i żywoty świętych. Wielkie centra produkcji obrazków znajdowały się w Belgii, Włoszech i Niemczech ${ }^{5}$.

W XVIII wieku we Francji ważnym ośrodkiem produkującym obrazki o tematyce religijnej było miasto Epinal ${ }^{6}$. Na przełomie XIX i XX wieku znaczącymi centrami były Niemcy i Szwajcaria? ${ }^{7}$. W XIX wieku instytucje Kościelne także zaczęły zajmować się produkcją obrazków. Na kongresach ustalano podstawowe

${ }^{3}$ C. Silli, Un po'di storia http://www.deagostiniedicola.it/ARTICOLI/collezionismo/santini/index.html (dostęp wrzesień 2008 r.)

${ }^{4}$ A. Spamer, Das Kleine Andachtsbild: von XIV. bis zum XX. Jahrhundert, München 1980, s. 7.

${ }^{5}$ M. Jagiełło, Od świętości do codzienności, Konteksty, nr 1-2, Warszawa 2002, s. 143.

${ }^{6}$ Epinal - miasto w Wogezach na wschodzie Francji. W 1796 r. Jean-Charles Pellerin założył l'Imagerie (obrazkarnia), fabryczkę produkującą seryjnie obrazki. Drukowane obrazki o różnorodnej tematyce religijnej, historycznej, dziecięcej cieszyły się wielką popularnością. Do dzisiaj funkcjonuje określenie obrazek z Epinal. Grand Larousse Encyclopédique, t. 4, Paris 1961, s. 616; A. Mencwel, „Obrazkarnia” w Epinal, http://andrzejmencwel.pl/wp-content/uploads/2009/04/epinal. pdf (dostęp maj 2009).

${ }^{7}$ B. Calamari, S. DiPasqua, Holy cards, New York 2004, s. 11-13. 
normy obrazka dewocyjnego, zakładano towarzystwa, które kontrolowały rynek obrazkowy i broniły ustalonych przez Kościół norm stylistycznych ${ }^{8}$.

Obrazki „krążyły” po całej Europie bez względu na to w jakim języku były podpisy czy modlitwy na nich umieszczone. Dla kupujących nie miało to większego znaczenia, gdyż większość nie umiała czytać, a nadrukowany na obrazku tekst dodawał tylko tym przedmiotom atrakcyjności i tajemniczości. Ważnym ośrodkiem w XVI i XVIII w. produkującym (także do Polski) obrazki na wysokim poziomie był Augsburg9.

Na terenach Polski w XVI-XVII w. większość rozprowadzanych obrazków była $\mathrm{w}$ języku niemieckim i włoskim. Zjawisko to musiało być masowe, gdyż w 1621 roku na synodzie krakowskim przyjęto uchwałę o zakazie sprowadzania ich do Polski z terenu Niemiec ${ }^{10}$.

Niezależnie od wytwórców zagranicznych w kraju powstawały rodzime wytwórnie obrazków skupione wokół najważniejszych ośrodków pątniczych (m.in. Berdyczów, Jasna Góra, Kalwaria Zebrzydowska, Poczajów). Obrazki drukowano prawdopodobnie także w drukarni Akademii Zamojskiej ${ }^{11}$. W XVIII w. na Śląsk trafiały $\mathrm{z}$ ośrodka wydawniczego w Pradze, a potem z pogranicza morawsko-czeskiego (Kraliki Morawskie). W XIX w. w produkcji obrazków m.in. dla Polski wyspecjalizowała się Norymberga, umieszczając na nich napisy w języku polskim $^{12}$

Prekursorami masowego wytwarzania obrazków w Polsce były drukarnie warszawskie, krakowskie i częstochowskie. Obok obrazków wytwarzanych w drukarniach,

w końcu XVIII w. pojawiły się odbitki drzeworytnicze świętych wizerunków wykonywane przez twórców ludowych. Znaczącym ośrodkiem drzeworytnictwa ludowego w XIX wieku był Płazów ${ }^{13}$.

\section{Tematyka}

Od II Soboru Nicejskiego (787) Kościół katolicki przypisuje duże znaczenie wizerunkom świętych; zezwolono wtedy na kult obrazów ale podkreślono, że kult obrazów odnosi się do osoby przedstawionej na obrazie, a nie do samego obra-

\footnotetext{
${ }^{8}$ Jagiełło, Od świętości do codzienności, s. 143.

${ }^{9}$ R. Sękowski, O talizmanach i obrazkach, „Spotkania z Zabytkami”, 13 (1989) nr 5 (45), S. 53.

${ }^{10}$ R. Mazurkiewicz, Kultura polskiej kontrreformacji, http://www.staropolska.pl/barok/opracowania/kontrreformacja.html (dostęp maj 2009).

${ }^{11}$ Święte obrazki o tematyce Maryjnej - wystawa w Bibliotece Wyższej Szkoły Zarządzania i Administracji w Zamościu, http://www.wszia.edu.pl/wystawy/wystawa-nr-28/index.php (dostęp wrzesień 2008).

${ }^{12}$ Sękowski, O talizmanach i obrazkach, s. 53.

${ }^{13}$ Płazów był niegdyś miastem założonym na prawie magdeburskim w 1614 roku na mocy przywileju króla Zygmunta III Wazy. Nie osiagnęło nigdy dużego znaczenia, było jednak prężnym lokalnym ośrodkiem rzemiosła i wymiany towarowej (ob. w Diecezji Zamojsko-Lubaczowskiej), Wikipedia - wolna encyklopedia.
} 
$\mathrm{zu}^{14}$. Wizerunki Boga, Matki Bożej, Jezusa czy świętych były nie tylko na obrazie ale i w nim samym.

Prawie sto lat później, po II Soborze Nicejskim w Konstantynopolu ${ }^{15}$, oficjalnie sformułowano ważną funkcję obrazów świętych, a mianowicie edukacyjną. Obrazy miały być źródłem wiedzy, przekazywać zasady wiary, nauczać i przekonywać o słuszności dogmatów. Wtedy to stwierdzono, że obrazy mają być Biblią dla ubogich.

Postanowienia z Soboru Nicejskiego II dotyczące wizerunków przyjęto na Soborze Trydenckim ${ }^{16}$ na którym podkreślono, że dzieła sztuki religijnej mają spełniać inną rolę niż obrazy świeckie, także pod względem formy. Postanowienia te sprawiły, że sztuka sakralna wydzieliła się jako odrębny styl w sztuce. Zgodnie z nauczaniem Kościoła cześć oddawana wizerunkom jest w ten sposób okazywana Bogu i świętym.

Możemy wyróżnić dwie podstawowe funkcję jakie pełniły obrazki święte: nauczanie oraz pobudzanie do pobożności.

Od samego początku na obrazkach spotkamy bogactwo przedstawień ikonograficznych. Na obrazkach świętych znajdujemy przede wszystkim sceny z Pisma Swiętego (Boże Narodzenie, Wniebowstąpienie, Wniebowzięcie) i hagiograficzne (męczeństwa, otrzymania stygmatów, medalika, różańca, szkaplerza), wizerunki świętych, tajemnice pańskie i symbole religijne. Najczęściej są to wizerunki Najświętszej Marii Panny, Matki Bożej z Dzieciątkiem, Jezusa, kościołów i sanktuariów, sceny z życia męczenników, świętych i błogosławionych, wyznawców, dziewic. W XVII wieku popularne stają się przedstawienia symboliczne, sceny religijne i dydaktyczne ${ }^{17}$. Często są kopiami słynnych dzieł sztuki, obrazów czy rzeźb z kościołów i galerii ${ }^{18}$.

Obrazkom świętym przypisywano swego rodzaju patronat, osobiste przywiązanie do świętego, często na podstawie rodzaju męczeństwa świętego. Były też wyrazem pierwotnej potrzeby ochrony, opieki. Nieprzypadkowo najbardziej czczone były te postaci świętych, które chroniły przed chorobami - np. święty Roch, który zaraził się dżumą, czczony jako patron chroniący od zarazy, czy święty Bartłomiej, który był żywcem obdarty ze skóry, a jego wizerunek miał chronić przed chorobami skórnymi.

Często obrazkowi towarzyszy tekst modlitwy umieszczony pod obrazkiem lub na odwrotnej stronie. Na awersach znaleźć można także cytaty z Pisma Świętego, teksty pieśni kościelnych, informacje reklamujące miejsca święte, informacje o przyjętych sakramentach, uczestnictwie w Mszach św., nabożeństwach

${ }^{14}$ Sobór Nicejski II (787) - sobór powszechny biskupów chrześcijańskich zainaugurowany w Konstantynopolu, przeniesiony do Nicei i tam obradujący od 28 września do 23 października 787 roku. Na soborze uchwalono 22 kanony dyscyplinarne.

${ }^{15}$ Sobór Konstantynopolitański IV - sobór biskupów chrześcijańskich, zwołany na przełomie 869 i 870 roku w Konstantynopolu przez cesarza Bazylego I Macedończyka.

${ }^{16}$ Sobór Trydencki - sobór powszechny Kościoła katolickiego w latach 1545-1563.

${ }^{17}$ A. Manicka, Święte obrazki, Znak, R.LIII, nr 9(556), Kraków 2001, s. 105-106.

${ }^{18}$ Najczęściej są to kopie z dzieł renesansowych artystów takich jak: Fra Angelico, El Greco, Van Dyck, Raffael, Cranach, Michał Anioł, Donatello i in. 
i uroczystościach religijnych, składanych ofiarach, prośby o przekazywanie informacji o doznanych laskach.

Znane są także obrazki zawierające jedynie tekst modlitwy otoczony ozdobna ramką lub motywami roślinnymi. Dawniej częściej można było także spotkać obrazki dołączone do relikwii świętych lub będące dla nich oprawą ${ }^{19}$.

Charakter pamiątek mają druki (obrazki) popularyzujące miejsca święte i czczone w nich święte wizerunki. Upamiętniają one ważne uroczystości religijne (koronacje i peregrynacje obrazów, pielgrzymki papieży, ingresy i wizytacje biskupów, poświęcenia kościołów, jubileusze święceń kapłańskich i ślubów zakonnych, beatyfikacje i kanonizacje błogosławionych i świętych), popularyzują nabożeństwa (nabożeństwo Cudownego Medalika, różańca, Drogi Krzyżowej) prezentują najbardziej znane sakralne budowle, strzeliste katedry, ale i nowoczesne kościoły oraz przydrożne kapliczki ${ }^{20}$.

W ostatnim czasie modne są (wzorowane na protestanckich) obrazki przedstawiające widoki z natury opatrzone cytatami z Pisma Świętego. W Polsce, po wyborze kardynała Karola Wojtyły na Ojca Świętego stały się popularne obrazki z wizerunkiem papieża Jana Pawła II.

\section{Sposoby wytwarzania i nowoczesne formy}

Najstarsze obrazki były malowane na pergaminie i na papierze czy wyszywane na tkaninach (płótnie i jedwabiu). Pierwsze grafiki na papierze były dość prymitywne, otrzymane $\mathrm{z}$ rysunku wyciętego w drewnianym klocku (matrycy). $\mathrm{Z}$ czasem technikę drzeworytniczą zastapił miedzioryt, który urozmaicił formę obrazka o nowe środki stylistyczne. Odbitki drzeworytowe i miedziorytowe były ręcznie kolorowane farbami wodnymi ${ }^{21}$.

W Niemczech w pierwszej połowie XV wieku użyto po raz pierwszy dwubarwnego drzeworytu (każdy kolor nanoszony był odrębną matrycą).

W dobie renesansu, a szczególnie reformacji, zainteresowanie obrazkami w dalszym ciagu wzrastało. Przyczyną tego wzrostu było wprowadzenie do produkcji nowych technik i materiałów, spowodowane podróżami jezuitów na Daleki Wschód, a szczególnie do Chin. Przywozili oni stamtąd nowe pomysły i materiały (bibułka, jedwab), a także nowe sposoby kompozycji i ornamentyki.

Kolejną techniką wykorzystywaną przy drukowaniu obrazków była akwaforta oraz staloryt; pozwalały one na uzyskiwanie większych nakładów.

Wytwórcy obrazków poszukiwali ciagle nowych sposobów ich upiększania. Zdobiono je ręcznie wycinanymi ramkami, naśladującymi koronki. Pierwsze obrazki z koronką pojawiły się na początku XVI wieku w Niemczech. W wiekach XVII-XVIII, w okresie baroku i rokoka, pojawiają się zupełnie nowe materiały

19 Święte obrazki o tematyce Maryjnej, http://www.wszia.edu.pl/wystawy/wystawa-nr-28/index.php (dostęp wrzesień 2008).

${ }^{20}$ S. Groń ks., Święci na papierze, http://www.jezuici.pl/am/arc/arc_001.htm (dostęp wrzesień 2008).

${ }^{21}$ Lexikon für Theologie und Kirche, Bd. 1, Freiburg 1993, szp. 616. 
i metody ich wykorzystania. Obrazki zaczęto tłoczyć na złotych i srebrnych płatkach folii, naklejanych na papierze ${ }^{22}$.

W XVIII wieku pojawiły się koronki tłoczone w papierze. Do ich produkcji wykorzystywano matryce grawerowane, które umożliwiły produkcję obrazków w dużych nakładach. Często korzystano z technik mieszanych, np. wklejając kolorowy obrazek drukowany lub ręcznie malowany w środkowe pole koronkowej ramki. Czasami środkowe pole wyklejone było atłasem lub satyną i dopiero na to przyklejony był rysunek z figurą świętego. Do ciekawych przykładów należą obrazki z przyklejanymi zasuszonymi kwiatuszkami pochodzącymi ze świętych miejsc oraz kawałkami tzw. relikwii jak np. kawałkami drewna z krzyża świętego ${ }^{23}$.

Nowa technika wielobarwnego druku litograficznego (chromolitografia) pod koniec wieku XIX dała wielki impuls w rozpowszechnianiu świętych obrazków.

Na przełomie XIX i XX wieku obrazek święty rozwinął się bardzo pod względem formalnym, Przede wszystkim wyszedł poza papier i skorzystał z możliwości jakie dają inne materiały takie jak szkło czy tworzywa sztuczne. Zmieniła się również kolorystyka, porzucając delikatne barwy na rzecz kolorów żywych, krzyczących, dodatkowo wzbogaconych efektami iluminacyjnymi.

Na początku XX wieku rozwój fotografii, uprzemysłowienie, rozszerzanie się nowych ideologii i następujące wydarzenia społeczno-ekonomiczne w Europie sprawiły, że produkcja obrazków podupadła, bo zmniejszyło się zainteresowanie nimi. Wtedy pojawiły się nowe produkty: kartki świąteczne i pocztówki. W okresie międzywojennym ponownie wzrosło zainteresowanie obrazkami świętymi, które produkowano masowo. W wieku XX szybko rozwijały się nowe techniki drukarskie, które stwarzały nowe możliwości w produkcji obrazków świętych.

W roku 1960 we Włoszech zaczęto dystrybuować obrazki winylowe z efektami trójwymiarowymi i laminowane z podklejonym magnesem; można przyczepiać je do metalu np. do lodówki czy kuchenki. To nam pokazuje, że producenci zaczęli wymyślać coraz to nowe formy od zakładek książkowych poprzez obrazki laminowane razem z medalikami, aż po breloczki do kluczy. Wielkim hitem pod koniec XX wieku były obrazki święte naniesione na karty telefoniczne i bankomatowe.

XXI wiek to już zupełne zaskoczenie dla tradycjonalistów. Pojawiły się elektroniczne obrazki święte, które można przekazywać za pomocą Internetu czy smsem na telefon komórkowy ${ }^{24}$.

${ }^{22}$ B. Cabbara, Materialien und Produktionsverfahren Kleiner Andachtsbilder, w: Das Kleine Andachtsbild, hrsg. Von M. Beer u. U. Rehm, Hildesheim 2004, s. 20-30.

${ }^{23}$ M. Falzone del Barbarò, Santi di pizzo, Torino 1983, s. 9-19.

${ }^{24}$ Święty obrazek sms-em na komórkę. We Włoszech wprowadzono nową usługę dla posiadaczy telefonów komórkowych. Zamiast nosić obrazek zapewniającego opiekę świętego w portfelu, można jego wizerunek otrzymać sms-em. Wystarczy wcześniej wysłać wiadomość o treści „santo” (czyli święty). Koszt operacji to 3 euro. Sprzeciwiają się temu niektórzy przedstawiciele Kościoła, którzy uznają przedsięwzięcie za przejaw spłycania i komercjalizacji idei religijnych. Współzałożyciela firmy z Mediolanu, Barbara Labate, nie zgadza się z ich opiniami. Oponuje, że znalazła lukę w rynku i zareagowała na realne zapotrzebowanie. „Idziemy po prostu z duchem czasu. Myślę, że to przemówi za- 


\section{Jak dzisiaj funkcjonuje obrazek święty?}

Celem pielgrzymek są świątynie, a w nich obrazy czy figury czczonych świętych, których drukowane wizerunki pielgrzymi zabierają ze sobą. Wizerunki te czynią cuda i je przypominają, utwierdzają wspomnienia doświadczone w świętym miejscu ${ }^{25}$.

Obrazek święty wbrew pozorom nie należy w pełni do obszaru świętości ( $\mathrm{sac}$ rum), od początku swego istnienia uplasował się pomiędzy obszarem świętości a zwyczajności (sacrum a profanum). Od pojawienia się nowoczesnych form coraz częściej jest spychany do sfery profanum. Jednak pierwotna funkcja obrazka predestynowała go do świętości co jest cały czas podtrzymywane poprzez zwyczajowe myślenie jego odbiorców i wciąż wiąże obrazek ze świętością. Fakt, że przedstawia świętych, służy do modlitwy, naucza, a nawet chroni przed złem czyni go szczególnym rodzajem przedstawienia. Zawsze w całej swojej historii obrazek był przedmiotem bardzo osobistym; jako pamiątka przywoływał wspomnienia, jako podarunek budził pozytywne emocje.

Obrazek pełnił często funkcję amuletu lub talizmanu, chroniący przed nieszczęściem, a przynoszący szczęście, dający poczucie bezpieczeństwa. Obrazki święte zawsze otaczano szczególnym szacunkiem: jeśli zniszczył się to nie można się go pozbyć w żaden inny sposób, jak tylko poprzez spalenie. Poświęcenie obrazka jest czymś równie istotnym w jego funkcjonowaniu; jak dla człowieka przyjęcie sakramentu chrztu wprowadzającego go do religijnej wspólnoty, tak i obrazek staje się przedmiotem świętym.

Ten miniaturowy wizerunek, opatrzony często odpowiednim tekstem, stał się „cichym” elementem (towarzyszem) naszego życia; nosimy go przy sobie bo wierzymy w jego moc, jest jednocześnie amuletem, talizmanem i pamiątką.

Główna rola obrazka to rozpowszechnianie i zapamiętywanie fundamentalnych założeń wiary, jak również osobistych wydarzeń religijnych. Różnorodność przekazu, a także materiałów sprawiły, że obrazki stały się nawet przedmiotem kolekcjonowania.

Obrazki święte zaczęły znajdować swoje nowe przestrzenie funkcjonowania; dzisiaj spotykamy je na kartach różańcowych, kartach ślubnych, breloczkach do kluczy, znaczkach pocztowych i różnego rodzaju gadżetach przypinanych na agrafki czy przyczepianych na rzepy lub magnesy.

Rozprzestrzeniające się w ogromnym tempie formy kultury masowej, które w końcu XX wieku znalazły swoje idealne nośniki - Internet, telefon komórkowy - niezdołały całkowicie wyrugowaćtradycyjnychświętychobrazków. Istniejąimoż-

równo do młodych ludzi, jak i staruszek". Na razie w katalogu figuruje 10 świętych oraz osoby, które najprawdopodobniej zostaną wyniesione na ołtarze, m.in. Jan Paweł II, święta Łucja, święty Krzysztof, ojciec Pio, a nawet Benedykt XVI. Wśród znakomitości nie mogło zabraknąć samego Jezusa oraz ukochanej przez Włochów Madonny. Przedsiębiorcy zapewniają, że lista jeszcze się wydłuży. http://manager.money.pl/styl/ciekawostki/artykul/swiety;obrazek;sms-em;na;komorke,73,0,301897.html; http://www.santiprotettori. com/ (dostęp sierpień 2008).

${ }^{25}$ D. Freedberg, Potęga wizerunków, Kraków 2005, s.101. 
na powiedzieć, że cieszą się nieustannym szacunkiem. Bo chociaż w formie podobne do wizytówek czy kalendarzyków o wymiarach kart kredytowych, to jednak nie są wyrzucane do śmieci - jak wizytówki po pewnym czasie, czy kalendarzyki - po roku. Bo święte obrazki to coś więcej, niż zadrukowany kartonik.

\section{Bibliografia}

Bereza A., Sposób funkcjonowania wspótczesnego obrazka dewocyjnego, „Konteksty”, nr 1-2 (2002) s. 135-140.

Cabbara B., Materialien und Produktionsverfahren kleiner Andachtsbilder, w: Das kleine Andachtsbild, hrsg. von M. Beer u. U. Rehm, Hildesheim 2004.

Caillois R., Człowiek i sacrum, Warszawa 1995.

Calamari B., DiPasqua S., Holy cards, New York 2004.

Eco U., Sztuka i piękno w Średniowieczu, Kraków 1997.

Engels M. T., Das kleine Andachtsbild: Prägedrucke und Stanzspitzenbilder des 19. Jahrhunderts, 1983.

Falzone del Barbarò M., Santi di pizzo, Torino 1983.

Freedberg D., Potęa wizerunków, Kraków 2005.

Grabowski J., Ludowe obrazy drzeworytnicze, Warszawa 1970.

Groń S., Święci na papierze, http://www.jezuici.pl/am/arc/arc_001.htm.

http://msitko.wordpress.com/2008/01/03/swiete-obrazki-w-telefonach-nowosc-miej-swojego-swietego-zawsze-przy-sobie/.

Jagiełło M., Od świętości do codzienności, czyli o profaniczności obrazka dewocyjnego u schyłku epoki audiowizualnej, „Konteksty”, nr 1-2 (2002) s. 141-148.

Krejč A., Techniki sztuk graficznych, Warszawa 1984.

Manicka Anna, Święte obrazki, „Znak”, 53 (2001) nr 9 (556), s. 104-108.

Mazurkiewicz R., Kultura polskiej kontrreformacji, http://www.staropolska.pl/barok/opracowania/ kontrreformacja.html.

Mencwel A., Obrazkarnia, „Epinal”, http://andrzejmencwel.pl/wp-content/uploads/2009/04/epinal. pdf.

Olędzka-Frybesowa A., Drogami średniowiecznej Europy, Kraków 1997.

Sękowski R., O talizmanach i obrazkach, „Spotkania z Zabytkami”, 13 (1989) nr 5 (45) s. 53-54.

Silli Ch., Un po' di storia, http://www.deagostiniedicola.it/ARTICOLI/collezionismo/santini/index. html.

Spamer A., Das kleine Andachtsbild: von XIV. bis zum XX. Jahrhundert, München 1980.

Wystawa w Bibliotece Wyższej Szkoły Zarzązania i Administracji w Zamościu pt: Święte obrazki o tematyce maryjnej, 12 grudnia 2006 - 28 lutego 2007, http://www.wszia.edu.pl/wystawa28/ index.php?zaw=techniki_wykonywania. 


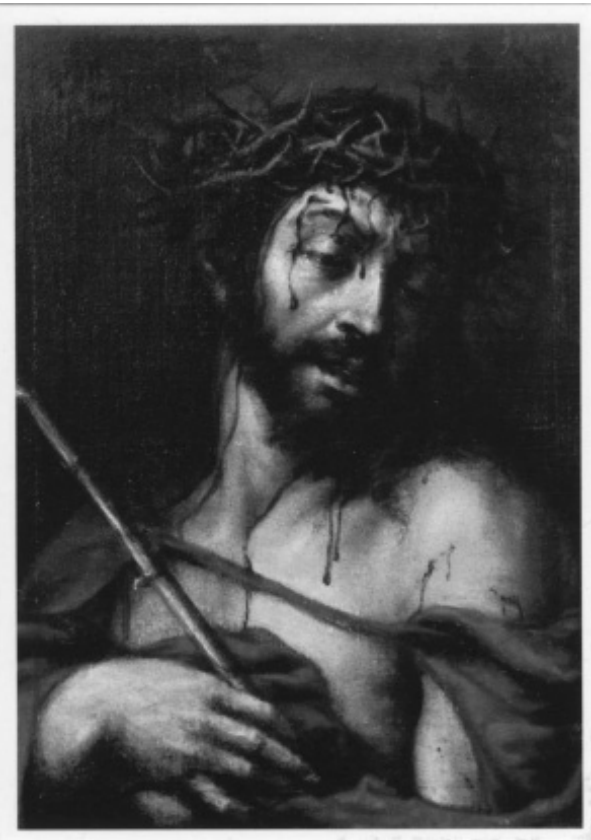

Chrystus Boleściwy. Fragm. obrazu Colijna de Corta

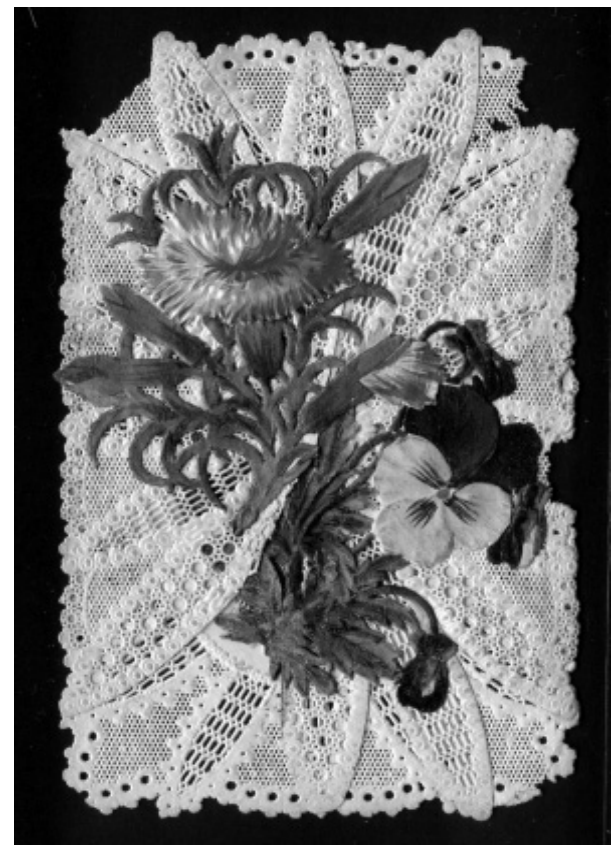

Kwiaty

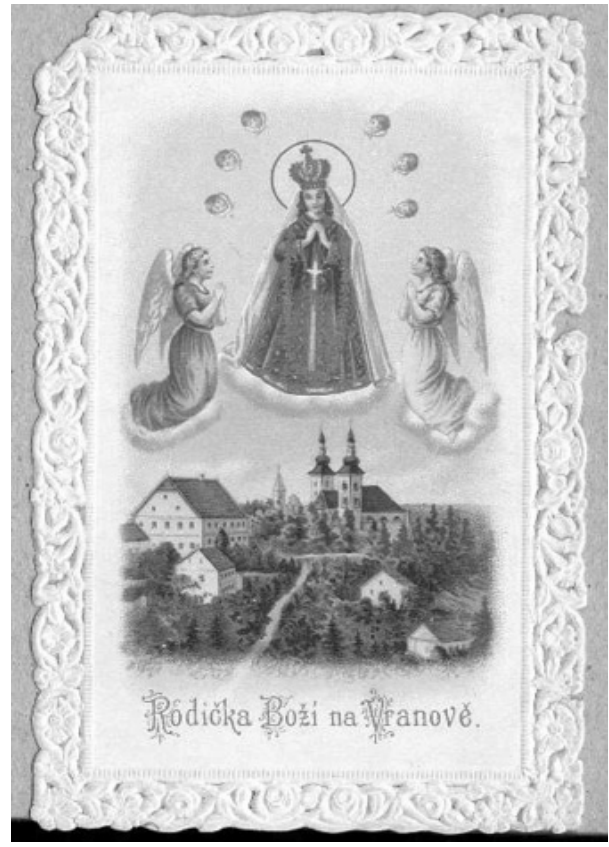

Kościół w Vranovie

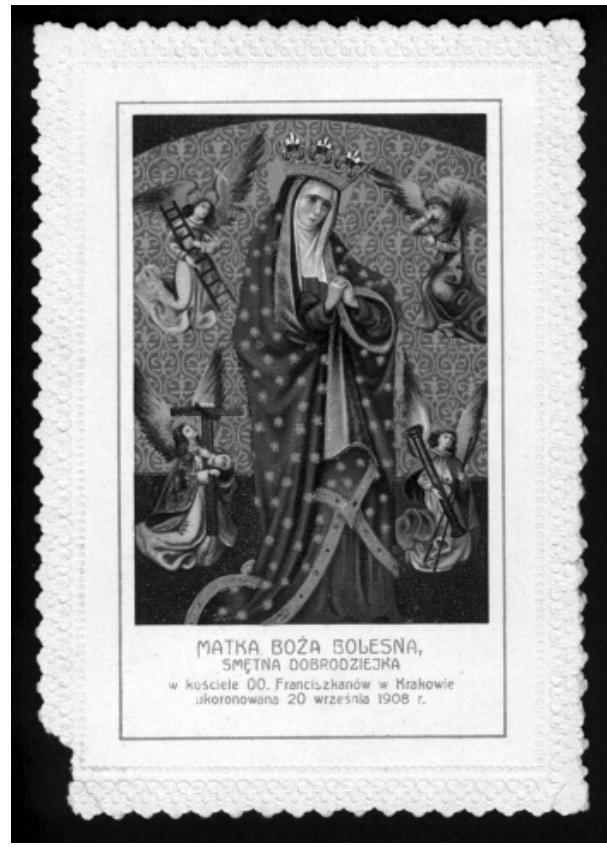

Matka Boża Bolesna 


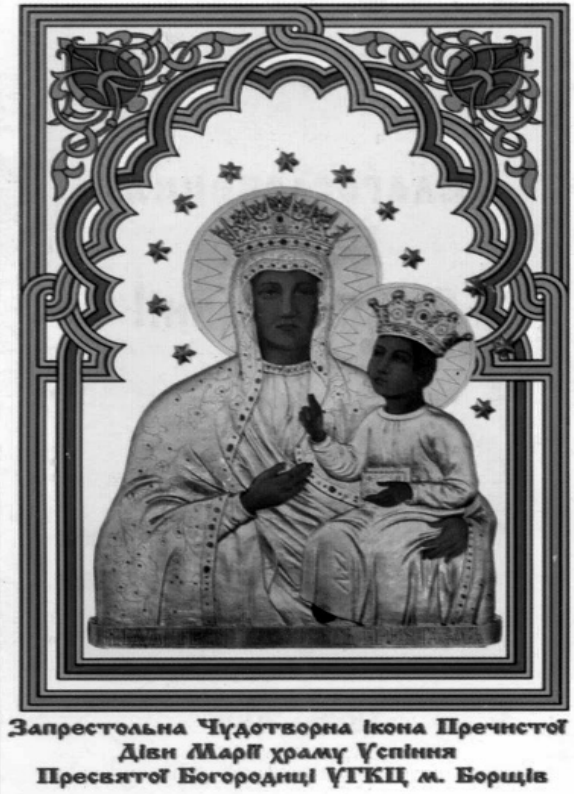

Matka Boża z Dzieciątkiem

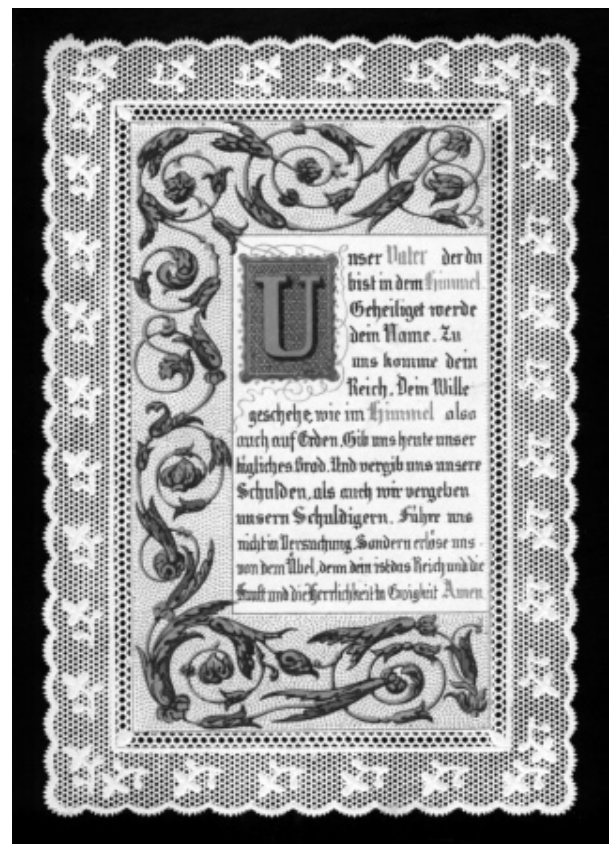

Modlitwa Ojcze nasz

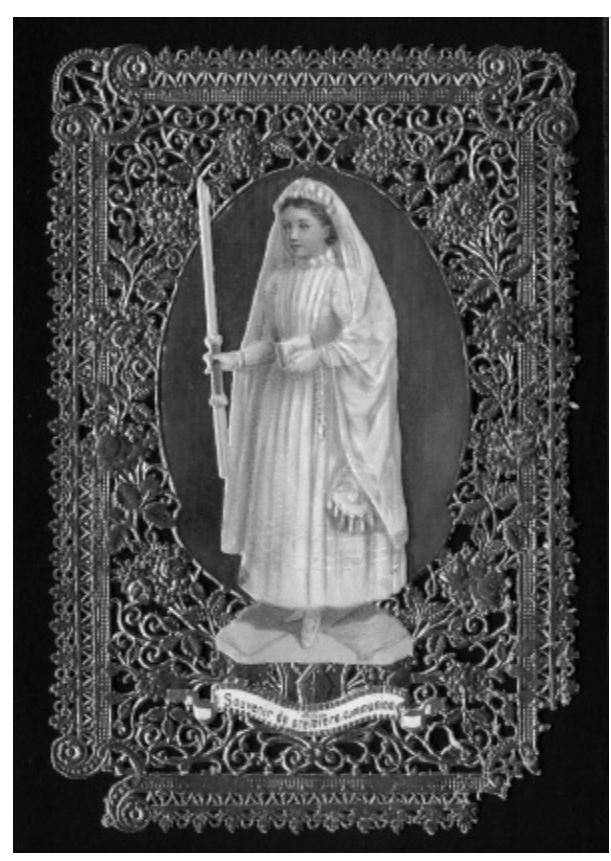

Pamiątka I Komunii świętej

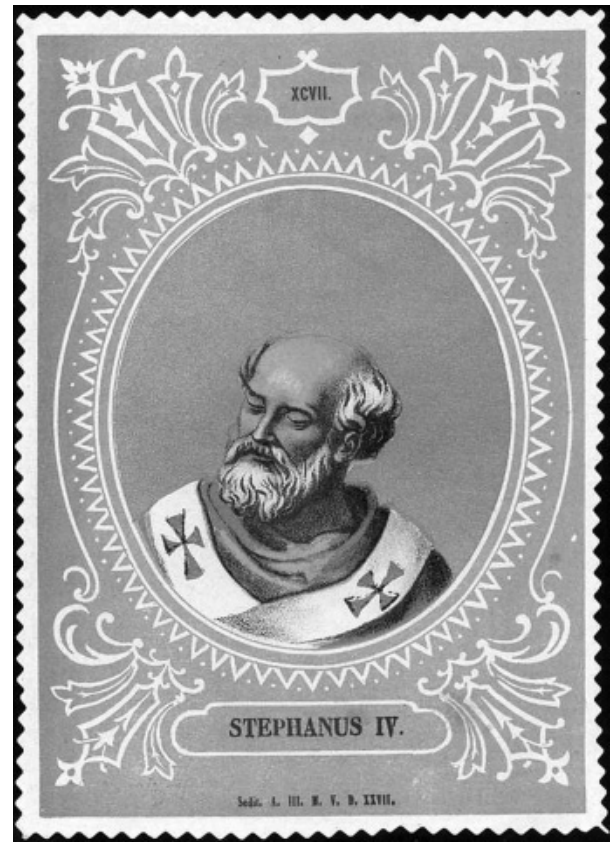

Papież Stefan IV 


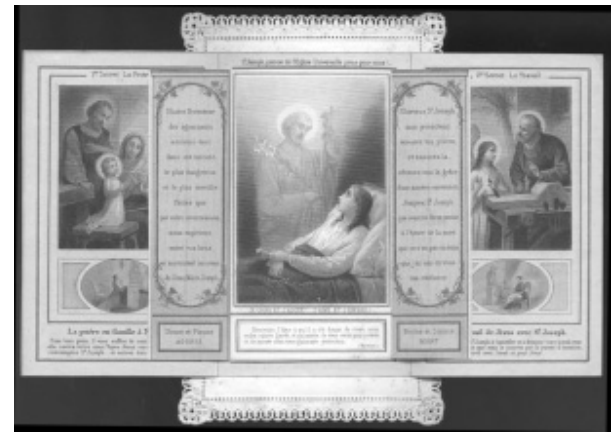

Św. Józef - Patron Kościoła powszechnego

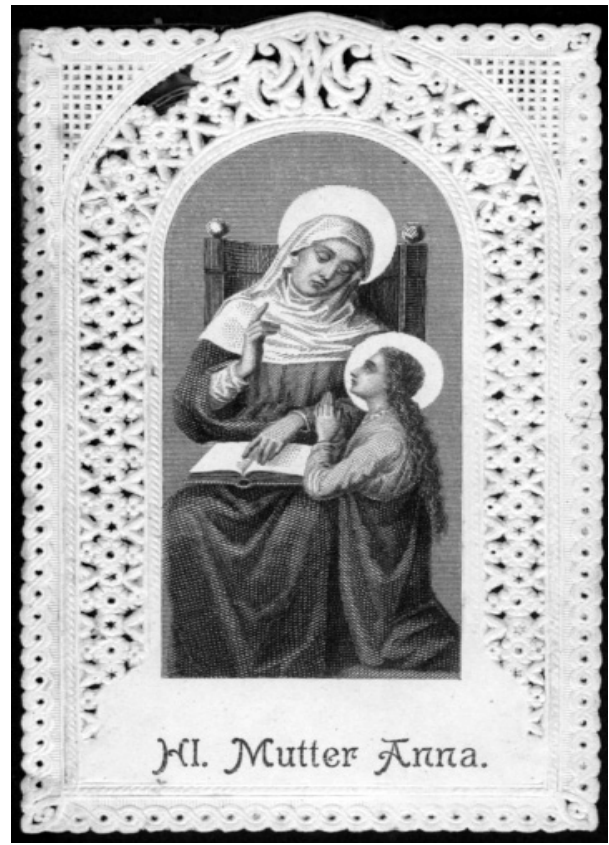

Św. Anna

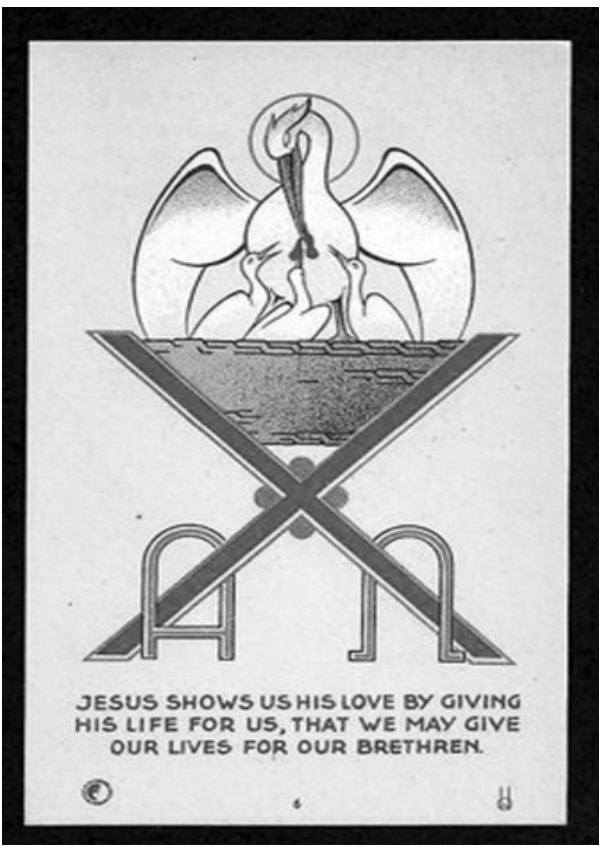

Symbole

Św. Józefa 


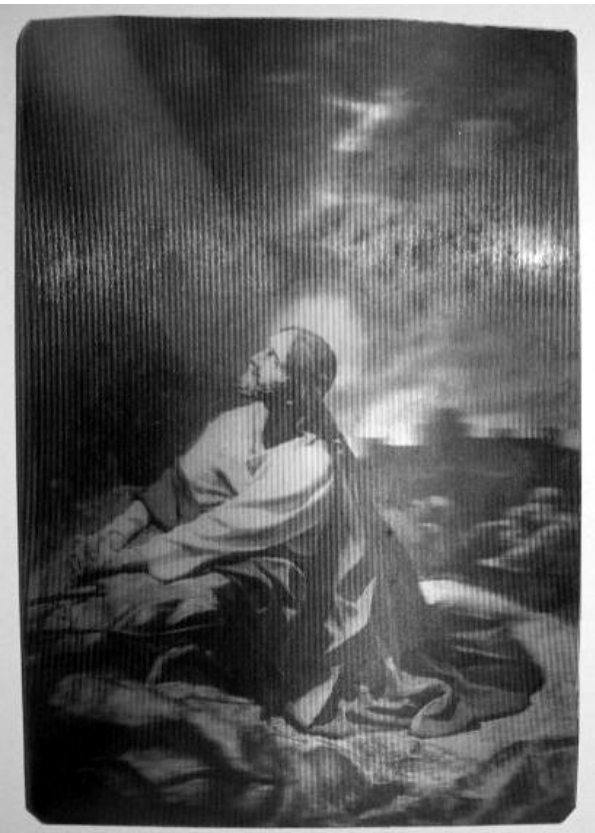

Obrazek trójwymiarowy

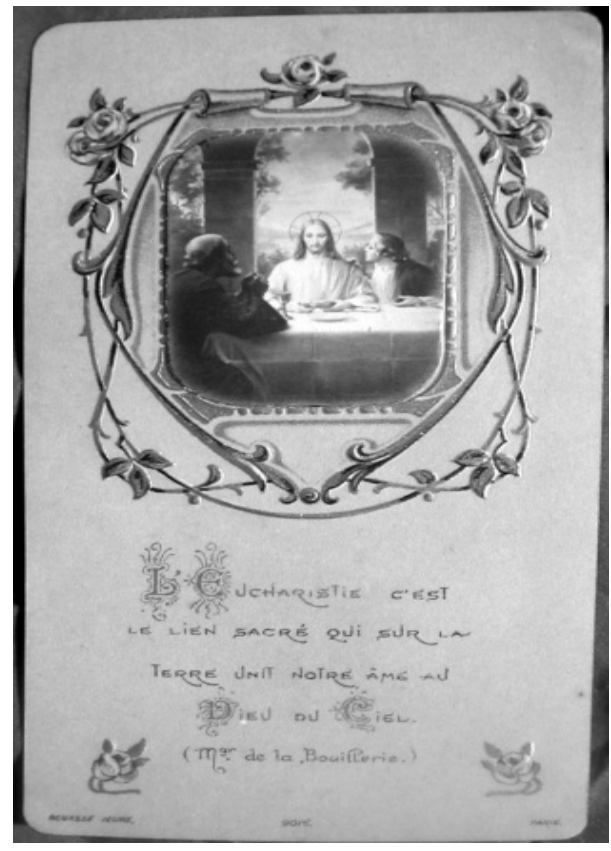

Celuloid

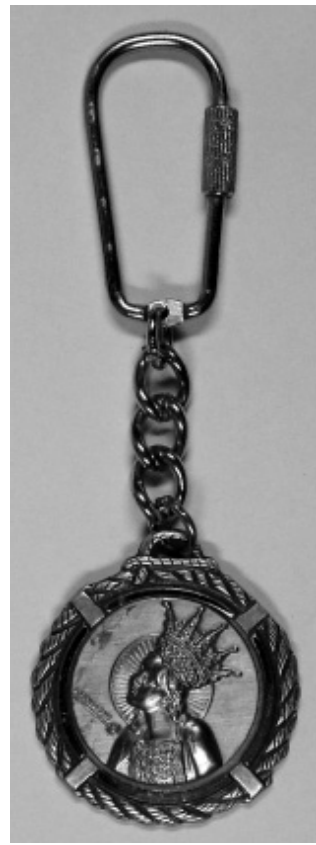

Brelok

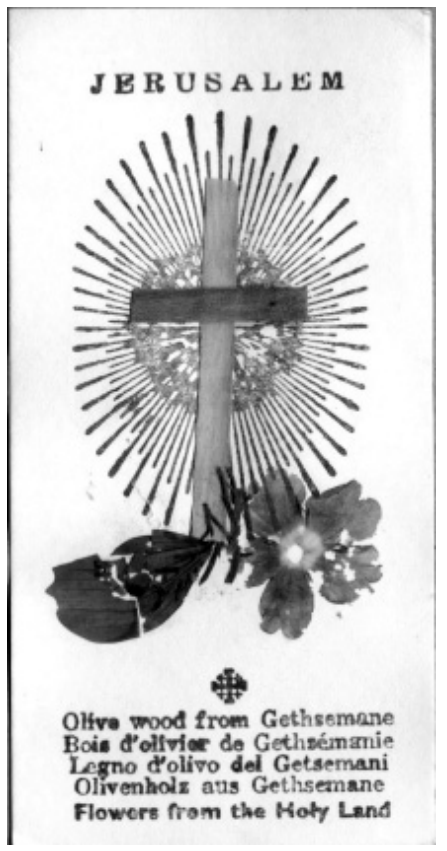

Drewno i suche kwiaty 


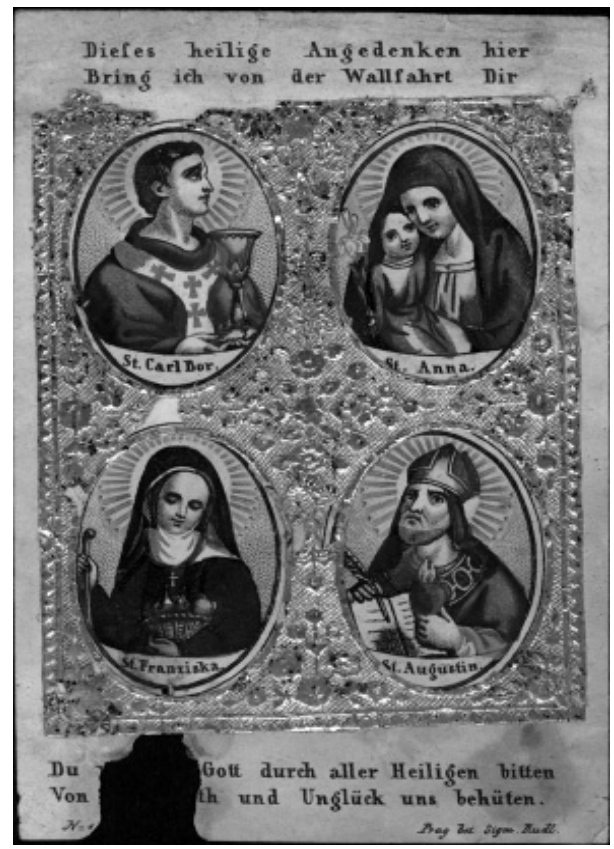

Folia złota

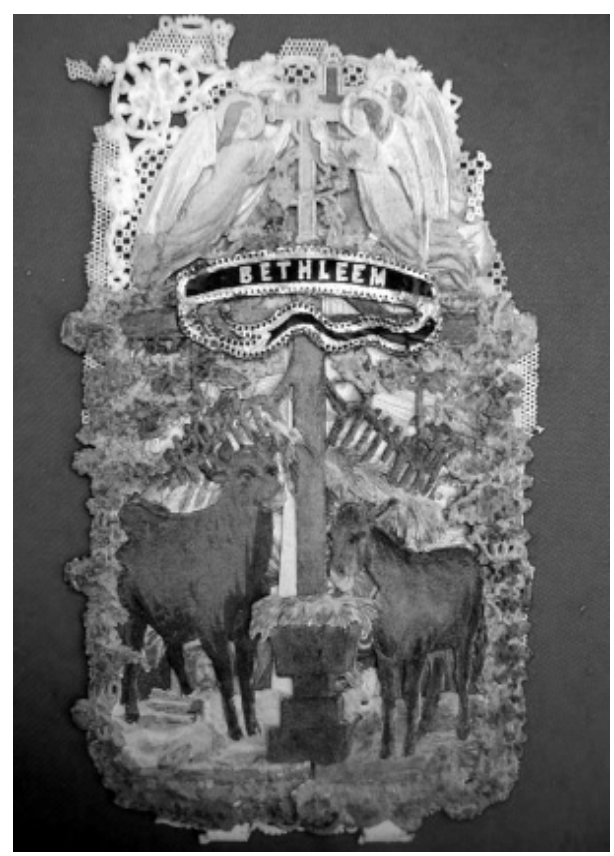

Kolorowe nici

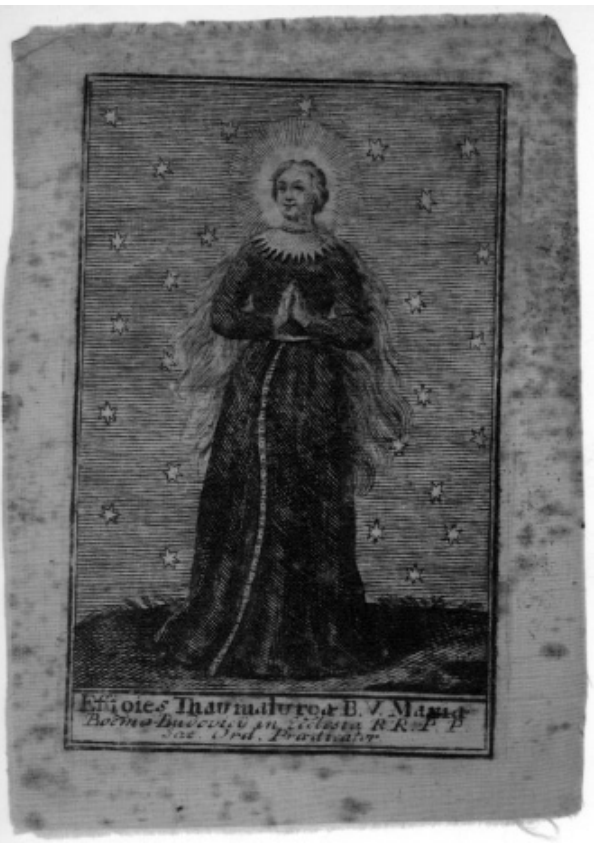

Jedwab

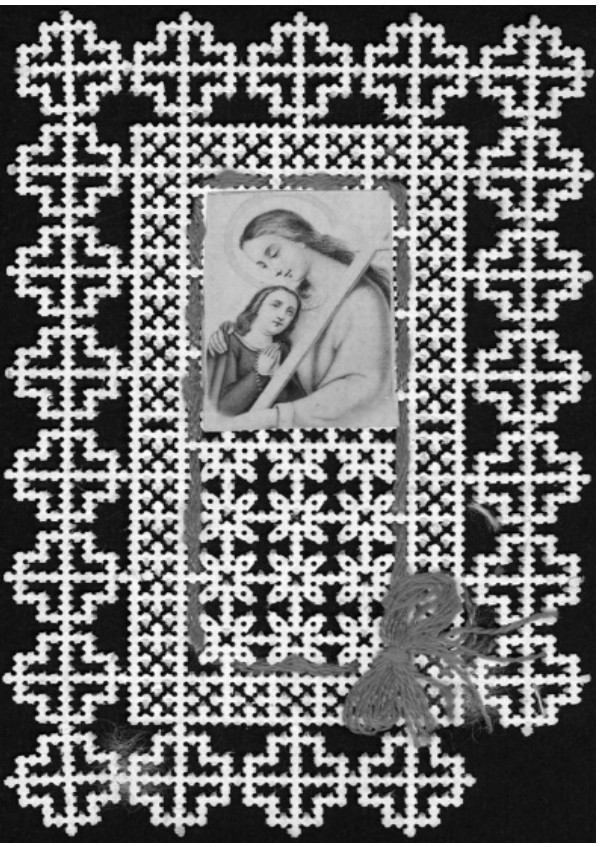

Koronkowy 


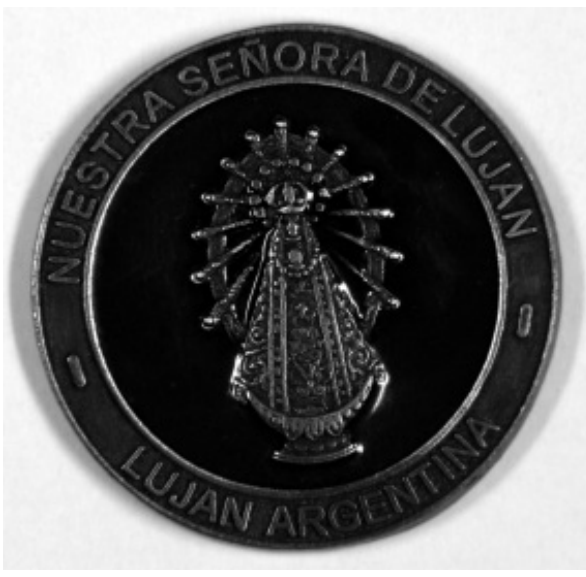

Medalion

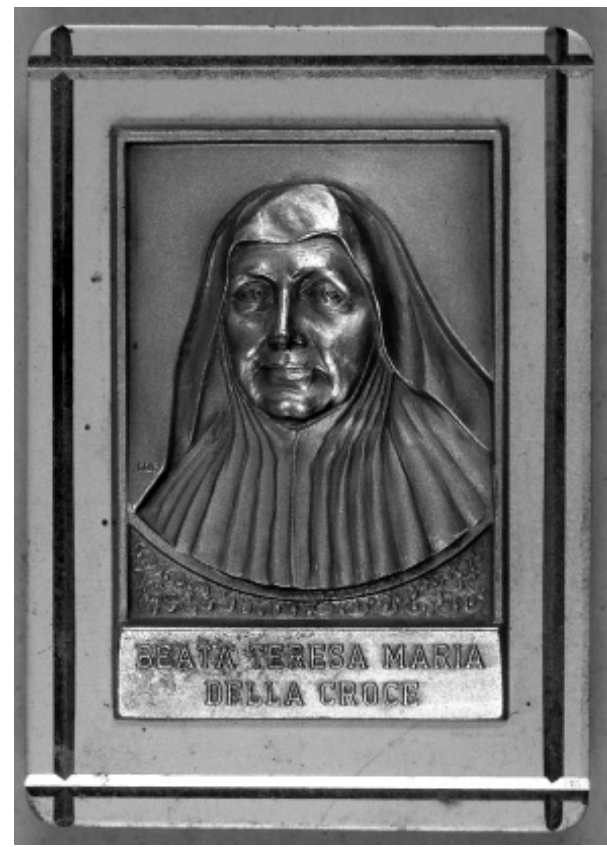

Metalowy

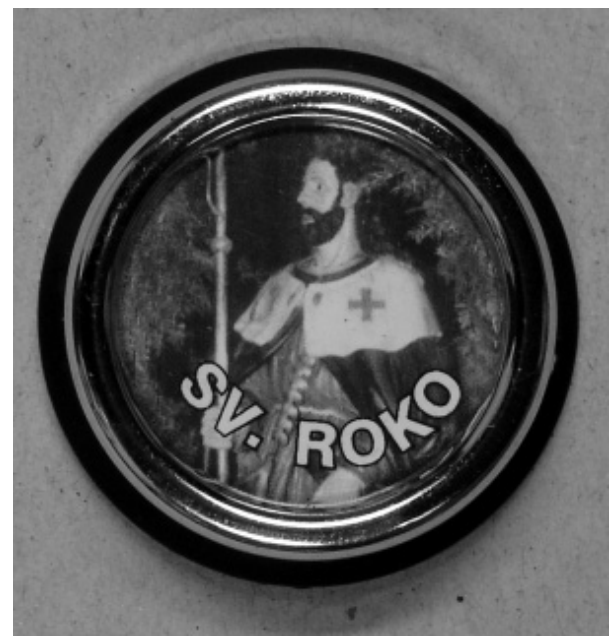

Na magnesie

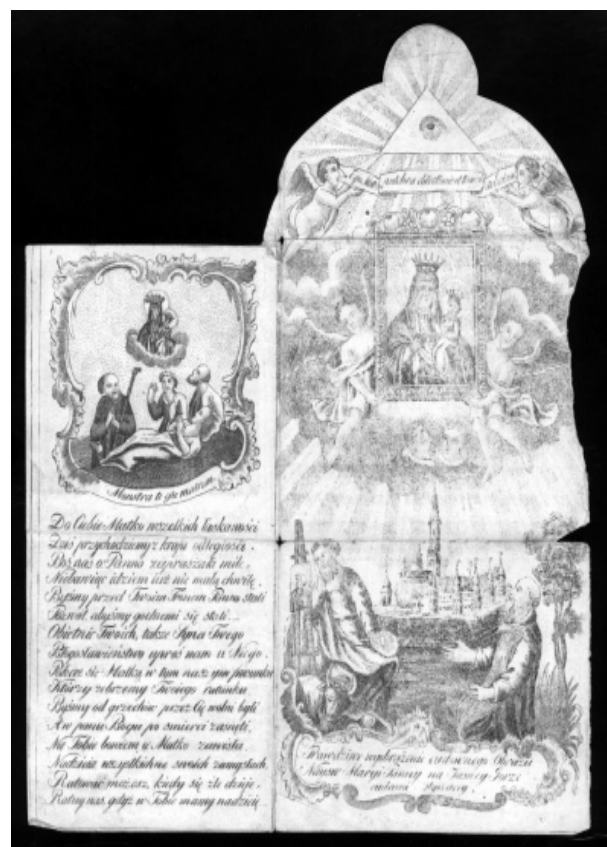

Odręczny 


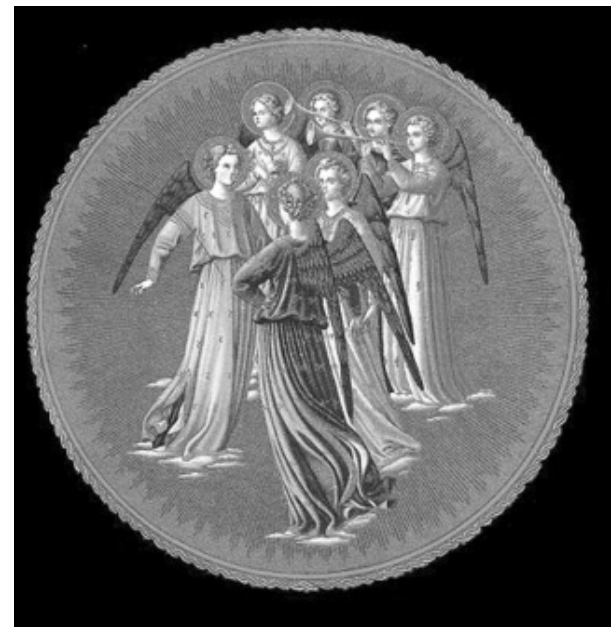

Okragły

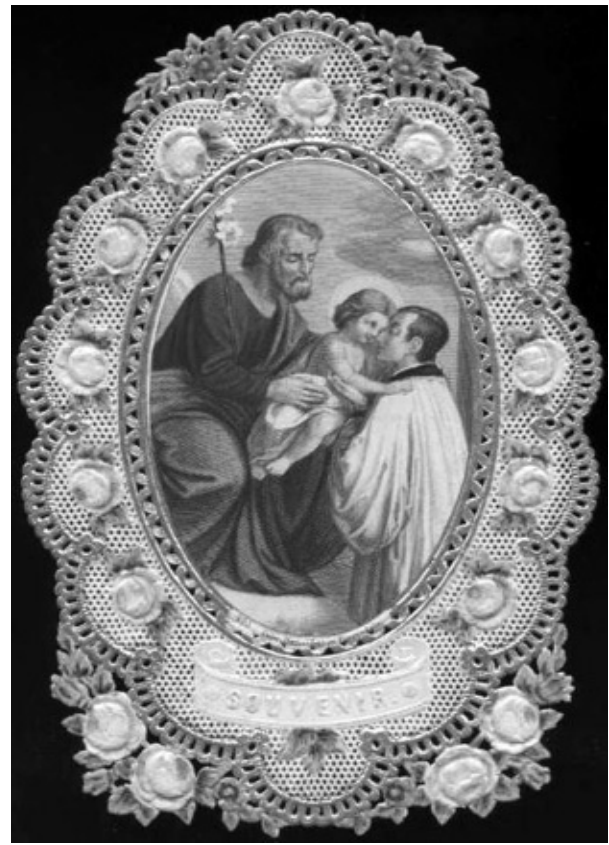

Owalny

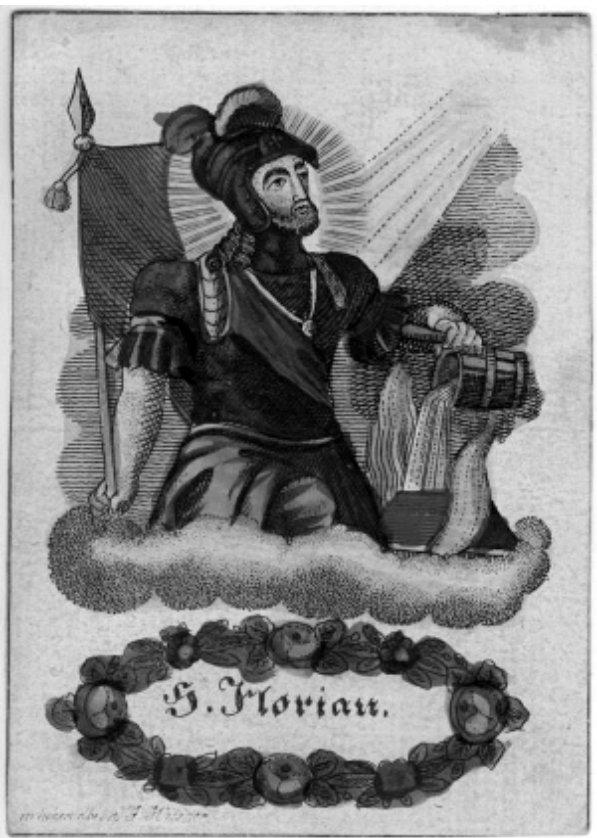

Staloryt ręcznie barwiony 


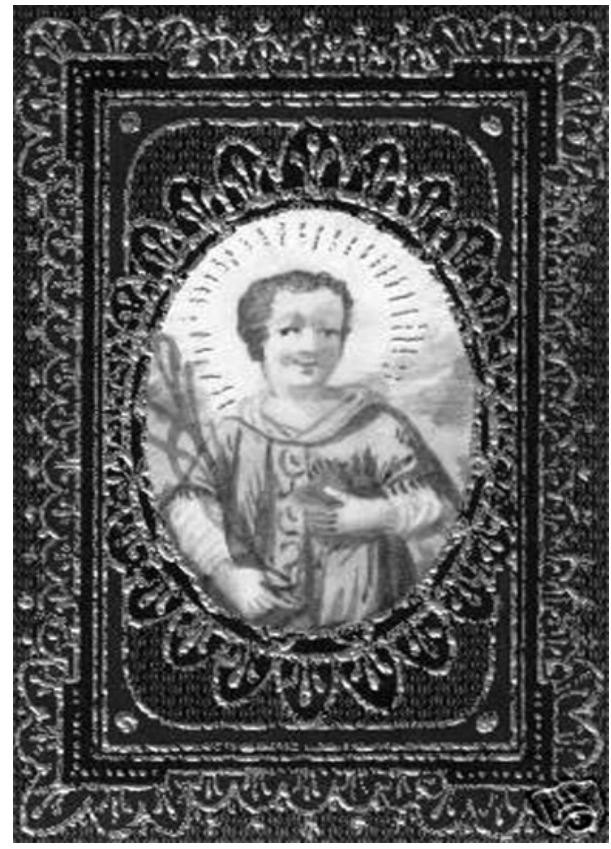

Wyszywany

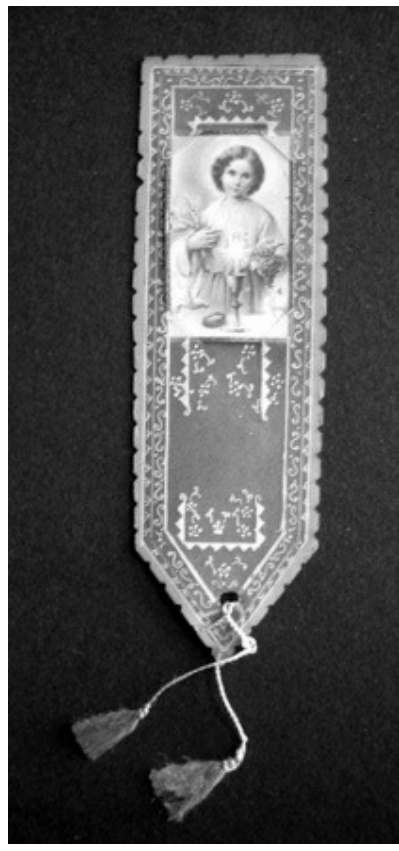

Zakładka

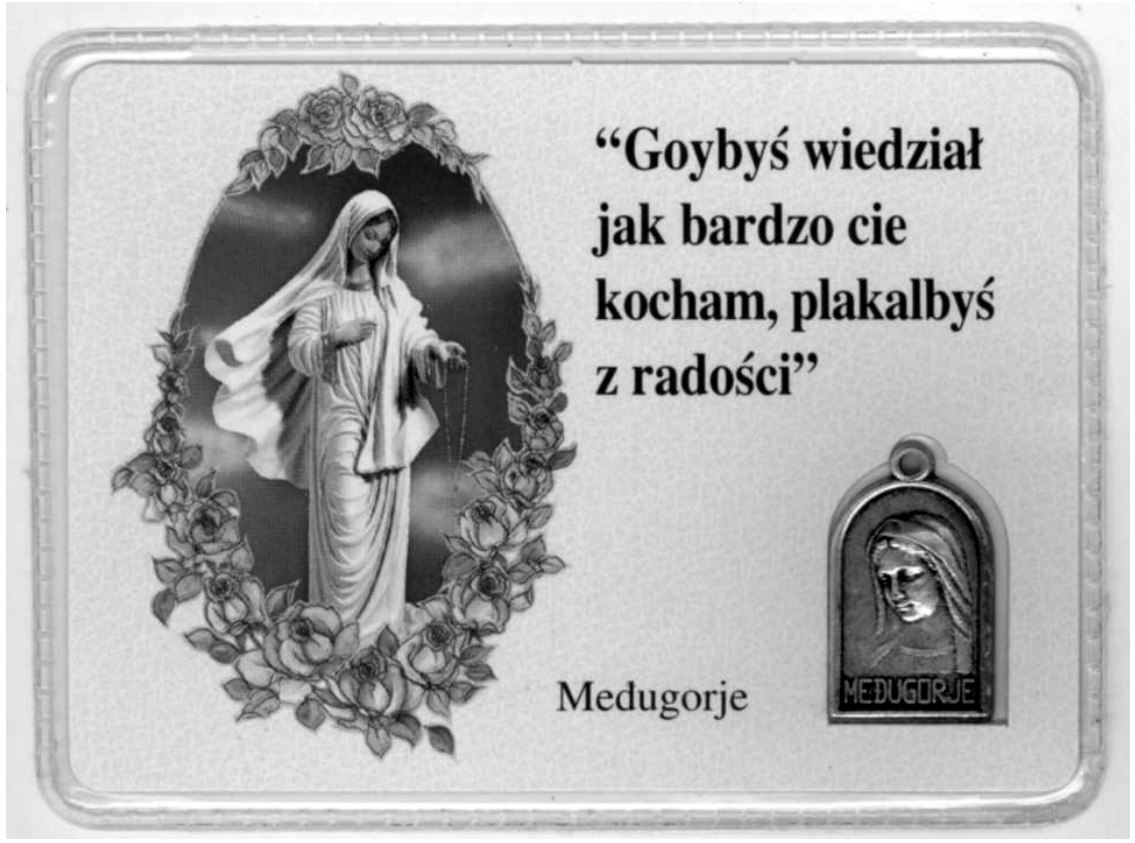

Zafoliowana kartka 